\title{
Africa's evolving vegetable seed sector: status, policy options and lessons from Asia
}

\author{
Pepijn Schreinemachers ${ }^{1}$ (D) Julie Howard ${ }^{2} \cdot$ Michael Turner $^{3} \cdot$ Simon N. Groot ${ }^{4} \cdot$ Bhupen Dubey $^{5}$. \\ Learnmore Mwadzingeni ${ }^{6} \cdot$ Takemore Chagomoka $^{7} \cdot$ Michael Ngugi $^{8} \cdot$ Victor Afari-Sefa $^{9}$ (D) Peter Hanson ${ }^{10}$. \\ Marco C. S. Wopereis ${ }^{11}$
}

Received: 23 July 2020 / Accepted: 20 January 2021 / Published online: 3 March 2021

(C) The Author(s) 2021

\begin{abstract}
Fostering better access to more nutritious foods across sub-Saharan Africa will be critical to ending hunger and malnutrition. In Asia, vegetable production and consumption have grown rapidly since the 1990s and the development of a dynamic vegetable seed industry, led by the private sector, played a pivotal role in this process. The availability of locally-bred and adapted varieties facilitated the rapid expansion of production and increased the supply of affordable vegetables to consumers. In contrast, the vegetable seed sector in sub-Saharan Africa has been slow to develop and has received little attention in the development agenda. Drawing from Asia's experience, this paper outlines a four-point strategy to accelerate the vegetable seed sector in sub-Saharan Africa. First, there is a need to strengthen the technical capacity of African seed companies to allow them to develop varieties that are well-adapted to local conditions and consumer preferences. Second, seed regulations, originally designed with food grains in mind, should be reviewed and revised to facilitate domestic vegetable breeding research and seed production. Third, more farmer extension is needed to exploit improved varieties together with good management practices. Fourth, vegetable marketing systems should be strengthened to reduce risks to farmers and traders. Investment in these four areas will help energize private sector investment in the vegetable seed sector. Asian experience suggests that investment in locally adapted vegetable varieties is a critical step in improving productivity, availability and ultimately consumption of nutritious vegetables.
\end{abstract}

Keywords Agriculture $\cdot$ Green revolution $\cdot$ Nutrition $\cdot$ Plant breeding $\cdot$ Private sector $\cdot$ Research

\section{Introduction}

Sub-Saharan Africa is not on track to meet its development target of ending all forms of hunger and malnutrition by 2030 (FAO, ECA and AUC 2020). In fact, hunger in sub-Saharan Africa is increasing across all regions, and almost $20 \%$ of the continent's population is undernourished, the highest in the world (FAO, ECA and AUC 2020). There is an urgent need

Pepijn Schreinemachers

pepijn.schreinemachers@worldveg.org

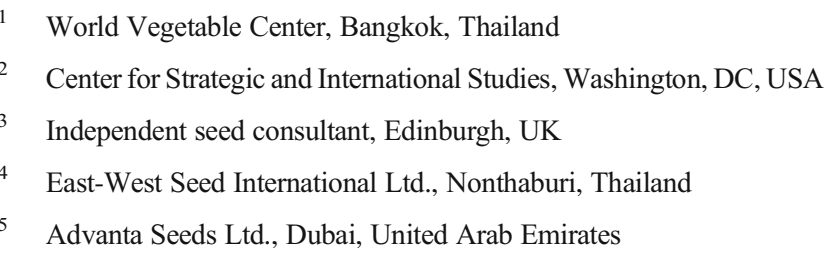

to tackle these economic and nutritional challenges through accelerated agricultural development. It is widely recognized that seed systems have an important role to play in this process because agricultural productivity remains low and the use of improved varieties is limited in almost all food crops (Walker and Alwang 2015). This deprives African farmers of the benefits of modern plant breeding, both to them directly as producers, and ultimately to the consumers they serve.

6

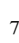

7 Seed Co West and Central Africa, Accra, Ghana

8 Simlaw Seeds Ltd., Nairobi, Kenya

9 World Vegetable Center, Cotonou, Benin

10 World Vegetable Center, Cotonou, Benin

11 World Vegetable Center, Tainan, Taiwan 
The prevailing strategy for seed system development in Africa is largely inspired by the experience of the Green Revolution in Asia, which introduced high-yielding varieties of rice and wheat linked to increased use of fertilizers and other agricultural inputs. There is abundant evidence that seed sector development for staple food crops was critical to increasing production (Evenson and Gollin 2003; Pingali 2012). Much less documented is the dramatic growth of vegetable production in Asia since the 1990s. This "Revolution of Greens", was driven by the private sector, whereas the first Green Revolution was led by the public sector. The growth of Asia's vegetable seed sector contributed significantly to expanded production and wider availability of vegetables to consumers at affordable prices (e.g., FAO 1999 for Thailand). However, the role of the vegetable seed sector as a key driver in this process has not been well-documented in the scientific literature, perhaps because public institutions and international donors played a relatively minor role.

This paper compares the available evidence on vegetable production, consumption, and seed sector development in Asia and Africa. Asia is here defined as South, East and Southeast Asia while Africa is defined as sub-Saharan Africa excluding South Africa. The paper draws lessons and suggests potential action points for strengthening the vegetable seed sector in Africa for the benefit of both farmers and consumers. The paper is based on an extensive literature review and on secondary data; it also draws from the personal accounts of the authors, several of whom have decades of practical experience working directly with leading seed companies and farmers in Asia and Africa. As such, the paper is intended to raise issues that may not have been properly considered before and warrant further discussion. It is not an empirical analysis or a systematic review of Asian and African vegetable seed sectors.

Much has been written about seed sector development in Africa but the literature focuses almost exclusively on the staple food crops and makes little or no mention of vegetables. Sperling et al. (2020) pointed out that strategies for seed sector development in Africa are often modeled on the maize seed sector but do not recognize that other crops are very different in terms of seed production and commercialization. This is also the argument of Louwaars and de Boef (2012) who warned against a linear approach to seed sector development in Africa and assuming that improved varieties produced by the formal sector will progressively replace farmers' seed systems of the informal sector. In fact, a widely-cited figure is that $80 \%$ of all seed used in Africa is produced in the informal system (Louwaars and de Boef 2012; Coomes et al. 2015). This paper adds to the literature by showing that the vegetable seed sector is very different from that of other crops and discussing the options for its development.

First, the vegetable sectors of Asia and Africa are compared and key factors affecting their different trajectories are analyzed. Next, the roles played by the private sector and the policy environment in vegetable seed sector development are reviewed. Against this background, lessons are drawn and a four-point strategy is proposed to stimulate the development of the vegetable seed sector in Africa.

\section{The vegetable seed sector in Africa and Asia}

The role of the seed sector in agricultural development became prominent with the introduction of high-yielding varieties of rice and wheat in Asia in the 1960s. The focus on staple grains at that time was understandable because hunger and malnutrition were primarily understood in terms of protein-energy shortage and the productivity of food grains was low. Seed production and dissemination of new high-yielding varieties of staple commodities were largely handled by the public sector at that time. The success of the Green Revolution in Asia in raising rice and wheat yields reinforced the idea that seed production was a public sector responsibility, a view that continued to influence policies during the 1970s and 1980s.

Aiming to replicate the Green Revolution, African countries established public seed enterprises during the 1970s with the support of international development agencies (Louwaars and de Boef 2012). Varieties bred by national research institutes were passed directly to these enterprises, which enjoyed a monopoly over seed production and distribution, but focused almost entirely on food grains and pulses (Tripp and Rohrbach 2001). The first seed laws and regulations, in Asia and in Africa, were prepared in the context of cereal crops and introduced a complex regulatory system of variety testing and registration, often followed by seed certification to ensure seed quality and protect farmers.

Vegetable seed was not a priority at the time, in Asia or in Africa. If public enterprises had vegetables in their portfolio, these were mostly locally produced open-pollinated varieties, or imports of old varieties from Europe and the United States. In Asia, only South Korea, Japan and Taiwan had major private seed companies active in vegetable breeding during the 1980s, and only Taiwan was producing varieties adapted to tropical environments. In most of Asia, the burden of regulations discouraged the entry of private companies and limited regional seed trade. Vegetable seed companies based in more developed economies were hesitant to enter the Asian market because they did not have suitable varieties and were not convinced that smallholder farmers would pay for quality seed.

The late 1980s and early 1990s saw a dramatic change in economic policy as it was argued that markets and private companies were more efficient in all areas of economic activity, including seed production (Cromwell et al. 1992). Seed laws and regulations were liberalized in Asia and Africa, 
public seed enterprises were privatized in many countries and in this more favorable climate, private companies started to enter the seed business. India liberalized its seed sector in 1988 (Pray et al. 2001), Ghana in 1989 (Kuhlmann and Zhou 2015), Tanzania in 1991 (Schreinemachers et al. 2017a), Philippines in 1992, Zambia in 1994 and Kenya in 1996 (Das et al. 2019). In China, the government gradually released control of vegetable prices from 1984 and by the early 1990s prices of all vegetables were determined by the market and private companies were also allowed to engage in the seed trade (Ma et al. 2000). Despite the commonalities in policy reform, a clear divergence in seed sector development could be observed, as described next.

In Asia, seed sector reform led to a rapid expansion of private sector activity in a wide range of crops (Pray and Nagarajan 2014). For example, India experienced rapid growth in hybrid seed production of cotton, pearl millet, sorghum, maize and vegetables (Kolady et al. 2012; Pray et al. 2001). Private seed production of non-hybrid crops such as rice and wheat seed also benefited, but to a lesser extent (Matuschke et al. 2007; Spielman et al. 2013). In India, it is estimated that F1 hybrids now occupy about $70 \%$ of the vegetable market by value - beans, peas, eggplants and onions being the exceptions (Advanta 2019). The value of the Indian seed industry is about USD 2.8 billion and is expected to double in the next 5 years (The Economic Times 2018); within this total, vegetable seeds contribute about USD 0.63 billion. China, Thailand, Indonesia, and the Philippines, and more recently Bangladesh and Vietnam, have also experienced strong growth in the private seed sector with vegetables being a major component.

In contrast, seed sector reform in Africa has not yet led to an expansion of hybrid seed production with the notable exception of hybrid maize (Erenstein and Kassie 2018; Smale et al. 2011). The use of improved maize varieties in subSaharan Africa (excluding South Africa) was less than 5\% of the area in the early 1980s and increased to $57 \%$ in 2014 ( $36 \%$ hybrids and $21 \%$ open-pollinated varieties) (Abate et al. 2017). Average maize yields have grown by about $1.6 \%$ annually from 2000 to 2016 (FAOSTAT 2019). During this time, public sector support for maize production has been substantial with improved varieties coming from the public sector, and increasingly from the private sector. In some countries this was driven by generous subsidies for seed, fertilizers and farmer extension (Abate et al. 2017; Gray and Kohl 2016; Smale et al. 2011). Despite this support, formal seed systems for staple crops remain weak in sub-Saharan Africa with only $35 \%$ of the area under food crops planted to improved varieties and a slow rate of diffusion (Walker et al. 2015).

Seed sector reform in Africa has also led to the emergence of vegetable seed companies, but at a much slower pace than in Asia, and mostly in East and Southern Africa rather than West and Central Africa. In
Tanzania, the first private seed company (Alpha Seed) was established in 1994 and sold open-pollinated tomato varieties. There are now about 25 vegetable seed companies operating in Tanzania and the total value of the sector is expected to grow from USD 25 million in 2018 to USD 65 million by 2023 (Guijt and Reuver 2019).

Most of the new private companies in Africa have built a business around trading and distributing seed but unlike Asia, few have invested in R\&D to develop their own locally-adapted varieties (Afari-Sefa et al. 2012). There is very little breeding of vegetables or other crops for the domestic market in sub-Saharan Africa despite the entry of several multinational seed companies (Access to Seeds Index 2019a, 2019b). Much of the vegetable seed is still imported from outside the continent, while local companies continue to produce seed of open-pollinated varieties. Some open-pollinated varieties have seen spectacular adoption; for instance, two improved tomato varieties developed by the World Vegetable Center accounted for $82 \%$ of the tomato area in Tanzania in 2014, and one improved African eggplant variety accounted for nearly all of the area planted with that crop (Schreinemachers et al. 2017a). Although impressive, the longevity of these varieties in the market reflects the limited choice available to farmers and the lack of competition.

A key difference between Asia in the 1990s and Africa now is the greater availability of trained specialists in Asia. Countries such as China, India, Philippines and Thailand had a high density of agricultural universities, often modeled on the United States model of land-grant universities, that supplied many quality graduates in plant breeding and other agricultural disciplines (Mehta et al. 2017; Traimongkolkul and Tanpichai 2005). The lack of domestic breeding capacity in Africa is not just an issue for vegetables but also for other crops (see Beintema and Stads 2017 for an account of public sector research). In countries where the public system has qualified plant breeders, they mostly work on staple food crops but rarely on vegetables. Afari-Sefa et al. (2012) pointed out that the Tanzanian national horticultural research institute did not have a single vegetable breeder in 2012.

The global vegetable seed market, excluding farmersaved seed and seed from public institutions, was valued at USD 6.2 billion in 2018 (IHS Markit Agribusiness Consulting 2019). It is estimated that on average seed companies re-invest about $15 \%$ of their sales revenues into research and development, which suggests annual investments of USD 930 million (IHS Markit Agribusiness Consulting 2019). With only a handful of seed companies doing vegetable research in Africa, we estimate that only about USD 5 million is spent on 
vegetable $R \& D$ by the private sector in sub-Saharan Africa. This would be $0.5 \%$ of global investments while the sub-continent accounts for $14 \%$ of world population.

\section{Vegetables, nutrition and economic development}

\subsection{Africa's nutritional challenges}

For most of the twentieth century, the immediacy of hunger required a focus on crops rich in energy and protein. Yet, this narrow focus no longer serves the nutritional challenges facing Africa and the rest of the world today. Current estimates for subSaharan Africa show that hunger affects $23 \%$ of the population (FAO, ECA and AUC 2020) while 39\% of women (15-49 years) and $62 \%$ of children (6-59 months) in the whole of Africa are anemic (WHO 2015). At the same time, $42 \%$ of Africa's adult population is either overweight or obese (WHO 2019).

These different forms of malnutrition have their origins in suboptimal diets, which globally are causing more deaths than any other risk factor (Afshin et al. 2019). The importance of a balanced diet that fulfills all nutritional needs from a diversity of food sources is increasingly recognized (Global Panel 2016; Willett et al. 2019). Vegetables are a vital source of vitamins, minerals, phytonutrients and dietary fiber, while low consumption of vegetables is an important risk factor contributing to mortality (Afshin et al. 2019). Africa is the only region where the micronutrient density in the food supply has declined since 1980 (Beal et al. 2017).

The cost of providing the recommended quantities of micronutrients in the diet is relatively high compared to the cost of providing energy (Herforth et al. 2019; Hirvonen et al. 2020; Masters et al. 2018). Increasing the consumption of vegetables is considered one of the more sustainable approaches to address this nutritional challenge. Hence the availability and affordability of vegetables in particularly for poor people needs to increase.

Mean vegetable consumption was similar in Africa and Asia in the early 1990s, but steadily increased in most Asian countries over the next 25 years - with much room for improvement still, while remaining relatively unchanged for most African countries (Fig. 1). In sub-Saharan Africa in 2017, vegetable consumption was less than $100 \mathrm{~g}$ per capita per day across $73 \%$ of the countries, compared with only $38 \%$ of Asian countries. This contrasts starkly with the recommendation of $240 \mathrm{~g}$ daily consumption made in the dietary guidelines of the World Health Organization and the Food and Agriculture Organization (Kalmpourtzidou et al. 2020) and a recommendation of $300 \mathrm{~g} /$ day by the EAT-Lancet Commission on Food, Planet, Health (Willett et al. 2019). In fact, per capita vegetable consumption in Africa is the lowest of all regions in the world (Afshin et al. 2019; Kalmpourtzidou et al. 2020).
Moreover, global projections of food security to the year 2050 , incorporating the effects of income growth and climate change, suggest that the greatest challenge will be to increase the availability and affordability of foods that are more diverse and richer in micronutrients (Nelson et al. 2018). The gap between vegetable supply and demand is projected to remain large globally, but particularly so for sub-Saharan Africa (Mason-D'Croz et al. 2019).

The high cost of healthy foods such as vegetables is partly the result of policies biased towards the production of staple foods (Pingali 2015). Vegetable production in Asia expanded rapidly from 73 to $185 \mathrm{~kg}$ /capita/year from 1990 to 2016, as shown in Fig. 2 (FAOSTAT 2019). In comparison, annual vegetable production in sub-Saharan Africa, increased only from 32 to $47 \mathrm{~kg} / \mathrm{capita}$ in the same period (FAOSTAT 2019).

Income growth, a rapidly expanding urban population, and market reforms in countries such as China and Vietnam have been key drivers of increased vegetable production and consumption in Asia (Ali 2000). However, Africa is now the fastest urbanizing region in the world with the urban population likely to nearly triple from 2018 to 2050 (United Nations Population Division 2019). With rapid income growth, supermarkets will play an increasing role for urban consumers in Africa and several studies report a growing demand for healthier food items including fresh vegetables among the expanding middle-class (Cernansky 2015; Staatz and Hollinger 2016; Tschirley et al. 2015; Worku et al. 2017; Zhou and Staatz 2016). These trends are expected to increase Africa's demand for vegetables.

To create a better nutritional balance, agricultural research and development must shift its focus towards food systems that serve the future nutritional challenges of sub-Saharan Africa and address all forms of malnutrition. Our better understanding of the importance of diet diversity should be reflected in stronger investment in food groups that are under-consumed in order to increase their availability and affordability.

\subsection{Vegetable production, employment and income}

While grain crops will always be important, farmers cannot be lifted out of poverty by increasing yields of staple food crops alone. The increased supply of rice and wheat turned several Asian nations from net importers into net exporters of cereals and removed the threat of famine. Increased cereal productivity freed up land and labor for economic diversification (Dawe 2000) but also led to a long-term decline in prices thus benefiting cereal consumers (Timmer 2009). As a result, cereal farmers in Asia continue to be relatively poor, although there are far fewer of them now than in the 1960s.

To address this problem, smallholders need to diversify their production into more profitable farm enterprises (Birthal et al. 2013). Diversification into vegetable crops 


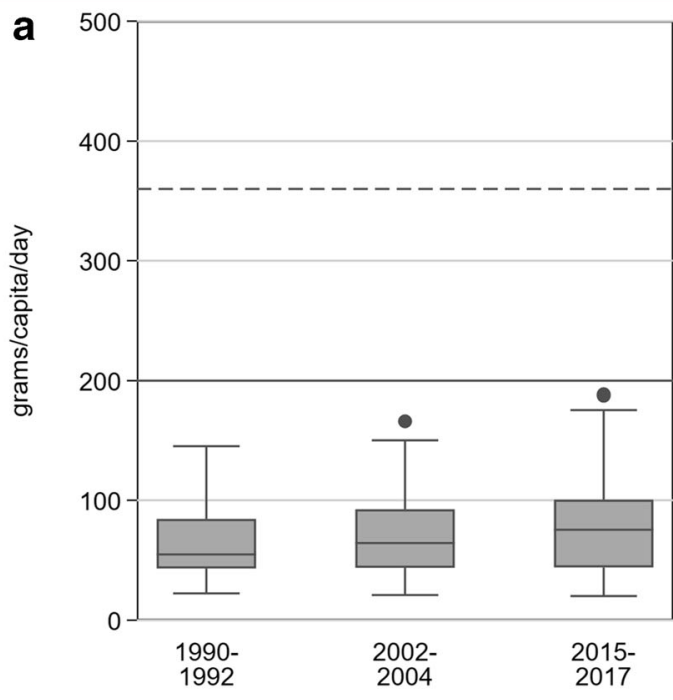

Fig. 1 Vegetable consumption in Africa and Asia, 1990-2017. Source: Based on data described in Afshin et al. (2019) and obtained from the authors. Notes: Data for 49 countries in Africa and 21 in Asia. Data refer to adults aged 25 years and above. Boxes show the 25 th and 75 th percentiles (interquartile range) and the median. The whiskers are 1.5 times

could play a key role in overcoming the economic challenges of poverty and unemployment in rural areas. Vegetable production can be profitable even on small farms; it generates a regular income stream as production cycles are shorter and less seasonally-bound, and consumer demand is rising (Schreinemachers et al. 2018). Being more intensive and less easily mechanized, vegetable production, processing and

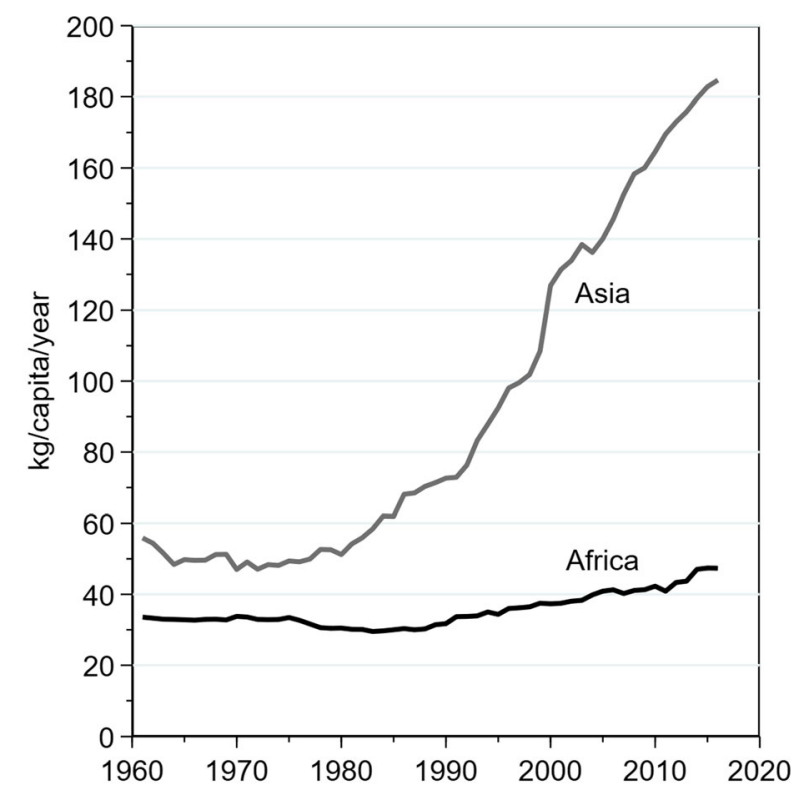

Fig. 2 Vegetable production per capita in Africa and Asia, 1961-2016. Source: FAOSTAT (2019). Notes: Vegetables based on FAO definition. Africa refers to sub-Saharan Africa but excludes South Africa. Asia refers to East, South and Southeast Asia

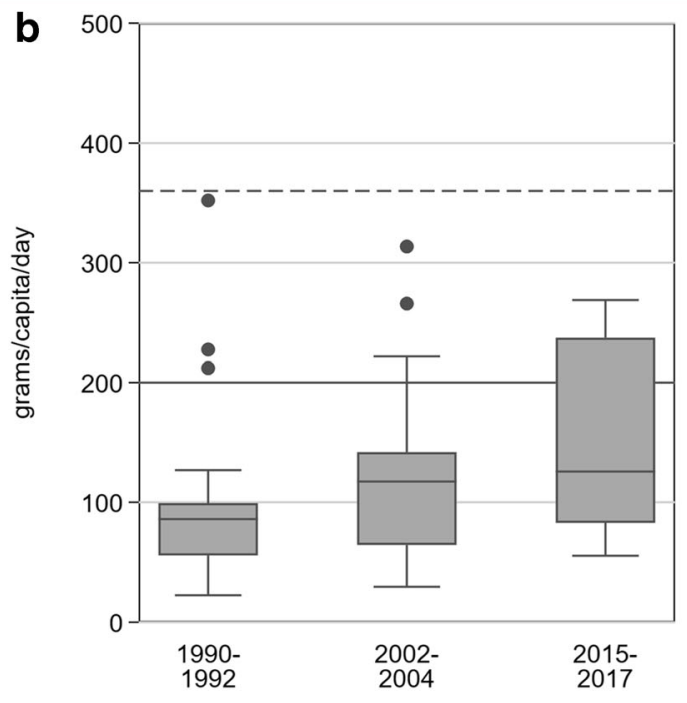

the nearest quartile. The dots are countries outside this range. The solid horizontal lines show the WHO/FAO-recommendation of $240 \mathrm{~g} / \mathrm{cap} /$ day (Kalmpourtzidou et al. 2020); the dashed lines show the mean recommendation of the EAT-Lancet Commission on Food, Planet, Health (Willett et al. 2019)

marketing can create additional employment in rural and peri-urban areas, which could benefit women and youth (UN 2015). However, market integration of smallholder farms is essential for unlocking this economic potential. Major challenges are poor access to markets, credit, purchased inputs, technology and extension services.

\subsection{Vegetable seed as a business}

It is important to recognize that in most Asian countries the private seed sector is less active in self-pollinated food crops such as rice, wheat, grain legumes and oilseeds (FAO 2020). Variety development and formal seed production of these crops remain to a large extent in the hands of the public sector, while the informal sector, comprising farmer-saved and community-based seed systems, continues to be the main source of seed, even in countries with an advanced seed industry (Fig. 3). The reason is that it is much less profitable to produce seed of self-pollinating grains and legumes. Market demand is limited because these crops naturally exist as stable pure lines and genetic quality therefore deteriorates only slowly when farmers save seed (Cromwell et al. 1992). Moreover, the market for these crops is relatively unsegmented, meaning that there are few distinct groups of buyers that require different products. These factors make self-pollinated field crops less attractive for the commercial seed industry. The exceptions are field crops in which a hybrid option became available, notably for rice in China, and for genetically-modified varieties, such as cotton in China, India and Pakistan. Hybrids of maize, sorghum, finger millet, and sunflower are also attractive as farmers buy seed regularly. 


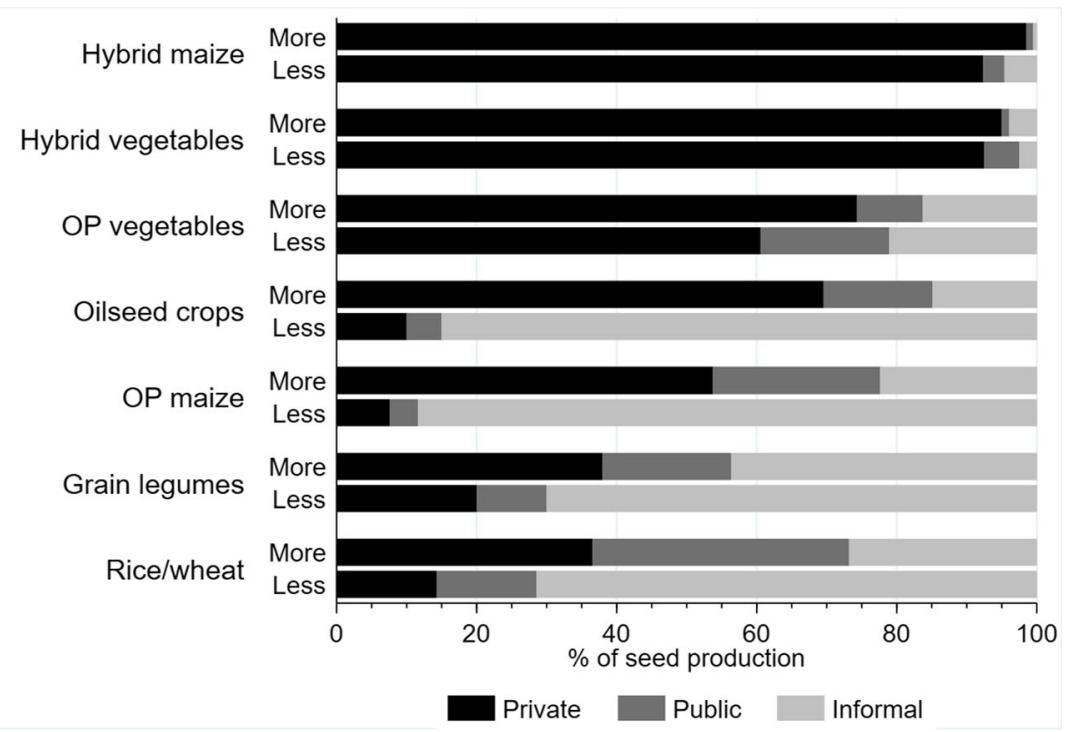

Fig. 3 Seed production of food crops by private or public formal sector or informal sector in Asia, by countries with a more- or a less-developed seed sector and by crop category, 2018. Source: Based on data described in FAO (2020). Notes: These are data from a questionnaire survey of private seed companies and national seed associations in Asia. "More" refers to countries with a more-developed seed sector (Bangladesh, China, India, Indonesia, Republic of Korea, Pakistan, Philippines,

In contrast to most self-pollinated field crops, vegetable seeds can provide a highly profitable business that enables companies to invest and expand their portfolio of products and services. The hybrid seed option is available for most economically important vegetables such as cucumber, eggplant, pepper, tomato and pumpkin. Hybrids give substantial benefits to farmers in terms of higher yield and uniform product quality, which is a key concern for modern retail outlets. Even non-hybrid vegetables are an attractive business for seed companies as it can be challenging for farmers to maintain seed quality. For instance, seeds of onion and some brassicas are difficult to produce because of the nature of their reproductive cycle (i.e., most of them require a second season under controlled climatic conditions to flower and produce seeds) and require more intensive management than can be done by farmers themselves. Moreover, many vegetables are highly cross-pollinating and quickly loose genetic puritycucurbits being prime examples. Even in Asian countries with a less-developed seed market, the private seed sector supplies most seed of open-pollinated vegetables as shown in Fig. 3. Hence, for many vegetable crops, regular seed purchase from a trusted source is the preferred option for farmers. Once connected to a reliable market, farmers are generally willing to repurchase seed for each production cycle.

Several other factors make vegetable seed production an attractive business. Vegetable seeds require little land and are much less bulky, and cost less to store and transport in comparison with cereals and grain legumes. For example, planting one hectare requires $40-100 \mathrm{~kg}$ of rice seed, but only $200 \mathrm{~g}$ of tomato seed. For this reason, the initial investment in physical
Thailand, Vietnam) and "Less" to countries with a less-developed seed sector (Malaysia, Myanmar, Nepal, Sri Lanka). Respondents estimated the percentage of seed produced by the private, public and informal sectors for each crop category. Values shown are medians (not weighted by country size) calculated over all countries in the data and scaled to $100 \%$. $\mathrm{OP}=$ Open-pollinated

facilities is much lower for a vegetable seed business, although more attention must be given to drying and packaging to maintain product quality and provide attractive presentation. Small seed packets can be easily sold by mobile traders or local vendors offering a range of other inputs, thereby improving access to vegetable seed.

In contrast to the cereal seed market, the vegetable seed market is much more segmented by species and by cultural preferences such as color, size, shape and taste, all of which provide opportunities for companies to focus on distinct market segments and establish their identity, thus reducing competitive pressure. Likewise, the low volume of seed production and low cost of transport allow companies to concentrate vegetable seed production in certain locations with favorable soil and climate conditions and where skilled labor is available. For India, it is reported that over one million people are employed in vegetable seed production, particularly in the manual emasculation and crossing for hybrid seed production, which require skilled labor and is mainly performed by women (Koundinya and Kumar 2014).

These technical and economic factors make vegetable seed production an attractive proposition for existing businesses to diversify and for new entrepreneurs to enter the market. For instance, seed companies in Africa that are breeding hybrid maize could diversify their portfolio with key vegetables and then gradually expand. This also happened in Asia where many seed companies initially prioritized seed production of tomato and chili pepper and then diversified their product portfolio into other hybrid and non-hybrid vegetables, and to other crops. 


\section{How to move forward?}

To develop a strong vegetable sector in Africa, one that is capable of delivering the nutritional and economic potential outlined above, the experience of Asia suggests that it will be important to strengthen the capacity of seed companies in Africa to develop their own vegetable varieties that are better adapted to specific growing environments in terms of resistance to pests and diseases and suitability for local soil and climatic conditions. While recognizing that Africa's trajectory of seed industry development will have its own distinctive features, we believe that the Asian experience holds important lessons. This section formulates four priorities to stimulate the development of the vegetable seed sector in Africa.

\subsection{Strengthen the capacity of African vegetable seed companies}

It is important for seed companies to strengthen their own breeding programs and to gain their own identity in the market place by meeting the needs of growers and consumers. The goal should be a diverse seed market in which many companies compete for market share by developing better products and services. However, it is challenging for small seed companies to establish their own breeding programs and enter hybrid seed production. They will face obstacles such as initial investment costs and difficulties in obtaining loans, lack of qualified specialists in breeding and hybrid seed production, and limited access to a range of germplasm.

With regard to human resources, existing capacity building programs in Africa are starting to embrace vegetable breeding alongside other crops. For instance, the West Africa Centre for Crop Improvement (WACCI) at the University of Ghana is training students in vegetable breeding. Other regional centers of excellence in plant breeding such as the African Centre for Crop Improvement (ACCI) at the University of KwaZuluNatal in South Africa and Makerere University in Uganda could put greater emphasis on vegetable crops.

One way to address these challenges is to form partnerships with international companies that could strengthen in-country vegetable breeding by infusing germplasm, know-how, equipment, and funds. Seed policy liberalization in India during the 1990s resulted in successful joint ventures between domestic and international seed companies that enabled Indian seed companies such as Mahyco, Indo-American, and Namdhari to become players in regional and global markets. Indeed, some Asian seed companies could play pivotal roles in building up the African vegetable seed sector (Glover et al. 2015).

Public research institutes within Africa are unlikely to become a major source of vegetable varieties for they are poorly resourced and do not have specialized expertise in these crops. Similarly, Asia's public research institutes are not an important source of vegetable varieties and they often lack a mechanism to license their varieties to the private sector (FAO 2020). Consequently, vegetable varieties released by the public sector often stay on the shelf (Schreinemachers et al. 2017b). A more suitable model, widely used in Asia, is public-private partnerships to accelerate the development of particular traits, for instance, those that address climate change and evolving plant diseases. Individual seed companies are naturally hesitant to invest in such complex traits with uncertain payoff and entering this area of research will require access to appropriate germplasm, reliable phenotyping platforms, and use of modern breeding methods. The World Vegetable Center, with regional offices across Asia and Africa, is well-placed to contribute to this and has established consortia with the private seed sector.

The Alliance for a Green Revolution in Africa (AGRA) and its Program for Africa's Seed Systems (PASS) has been a major source of investment. AGRA disbursed USD 462 million in project grants from 2007 to 2017 but the focus was entirely on staple food crops and pulses and none was for vegetables (AGRA 2018). The impact of AGRA in the targeted countries has been contested as its contribution to food and nutrition security remains unclear (Wise 2020). Nevertheless, the program did incubate many start-up seed companies in the cereal sector and built human capacity in plant breeding and other crop improvement disciplines. This may ultimately benefit the vegetable sector as these companies broaden their portfolio to more profitable crops.

\subsection{Create an enabling regulatory environment}

Seed laws and regulations were introduced to protect farmers from the risk of low-quality seed and to promote the adoption of improved varieties (FAO 2020). These national regulations - in Asia, Africa and elsewhere - were designed with field crops in mind, where few varieties are released annually and remain in the market for a decade or longer. High yields and wide adaptation are key criteria for variety evaluation and official release for these crops, a process that typically takes two to three years. It is unhelpful if these regulations are applied directly to vegetables because the plant breeding and market conditions are completely different (Turner and Bishaw 2016). Key changes to create a more favorable regulatory environment include the following.

Variety registration requirements The release of new varieties may require tests for Distinctness, Uniformity and Stability (DUS) and Value for Cultivation and Use (VCU), the latter commonly involving multi-location trials. Such requirements were originally intended to support the orderly marketing of seeds by providing information about the identity and performance of varieties in the major field crops (FAO 2020). Subjecting vegetable varieties to VCU testing requirements is 
problematic because many attributes that may be relevant for consumers (e.g., color, size, shape, texture, and taste) are not easily measured in a conventional field trial. Furthermore, government agencies do not have the resources to carry out these tests on a large number of varieties. Where these slow and costly testing procedures apply, seed companies will be reluctant to invest in vegetable research and will continue to rely on imported seed of established varieties, which usually only requires phytosanitary certification, but no registration. This has a negative effect on domestic breeding and innovation.

Recognizing these problems, Asian countries such as Thailand and the Philippines have adopted a simplified process of variety registration for vegetables that does not require VCU testing (FAO 2020). Thailand has an online registration process that requires a seed quality certificate from an authorized seed laboratory and the process takes less than a month to complete (AgConAsia Agriculture Consulting 2017). China and India do not even require variety registration for vegetables. In Africa, regulatory authorities in Malawi and Zambia do not require variety registration of vegetables in practice, even though it is mandated by law.

Foundation seed production Countries such as Tanzania and Mali mandate that foundation/basic seed (that is, seed used for multiplication to produce commercial seed) of varieties coming from the public sector is supplied by national seed agencies or other public institutes such as universities. To our knowledge, no country in Asia imposes such requirements on public sector varieties. Public organizations face capacity constraints to do this work properly and the consequences of poor management jeopardizes the quality of the seed produced. It is therefore important that seed companies are allowed to produce foundation seed of all vegetable varieties in their portfolio while holding them accountable for seed quality of the commercial seed. It is noted that this requirement would be unimportant if seed companies had their own proprietary varieties instead of relying on public sector varieties.

Seed certification Some countries (e.g., Tanzania, Kenya and Uganda) mandate that all seed produced domestically is certified by a seed certification agency. This can significantly increase the cost of domestically produced vegetable seed and create an incentive to import seed. Few countries have the capacity to provide an efficient certification service for vegetable seed so it may be better to rely on minimum seed quality standards and not to require seed certification. Zimbabwe and Zambia are examples that have exempted vegetable varieties from compulsory certification. China, India and Thailand are examples of Asian countries with a successful vegetable seed sector that do not mandate the certification of vegetable seed (AgConAsia Agriculture Consulting 2017).

Addressing counterfeit seed This is a problem in both Asia and Africa and particularly affects high-value hybrid seed of maize, in which grain can be dyed to look like treated seed and then sold as a hybrid. A study in Uganda found that $30 \%$ of the marketed maize seed is counterfeit (Joughin 2014). High value vegetable seeds are also at risk but regulatory agencies and law enforcement authorities in Africa give low priority to counterfeiting in vegetable seed as these are not considered strategic crops. However, without proper mechanisms to address this threat, seed companies will be reluctant to invest and prefer to do business in countries where they are better able to protect their brands. There is a lack of data and analysis about the scale of counterfeiting and low-quality seed of vegetables in Africa but a study on indigenous vegetables in Kenya suggested that the problem is significant (Croft et al. 2018). Hence, more regulatory attention needs to be given to point of sale inspection.

It is widely-cited that about $80 \%$ of all seed used in Africa is produced in the informal system (Louwaars and de Boef 2012). This share will be much lower for vegetables, especially among commercial vegetable producers (Schreinemachers et al. 2017a). Still, farmer-saved seed remains important for many traditional vegetable crops for which the formal sector offers few alternatives (Croft et al. 2018) and also for home gardens and semi-commercial farms. It is therefore important that the regulatory environment does not restrict the rights of farmers to develop their own vegetable varieties and produce and exchange seed. Farmer-saved seed does not limit the development of the formal seed sector because most commercial vegetable farmers will find it more profitable to purchase seed than to produce their own.

\subsection{Invest in extension systems and complementary technologies}

The switch from traditional to improved vegetable varieties and hybrids in Asia did not happen suddenly, but took at least 20 years in most countries and still continues. Adoption of improved varieties and hybrids is a process of behavioral change, which requires time and investment. It involves intensive efforts to demonstrate the benefits of improved varieties and good management practices. Irrigation, staking and trellising, plastic mulches, seedling nurseries, and protected cultivation are now commonly used by smallholders in Asia (Ali 2000), but are not readily available to farmers in sub-Saharan Africa. Adoption of these technologies allows improved varieties to express their yield potential. Public extension staff are ill-equipped for this role because they are mostly general-purpose extension officers who have no specialized competence in vegetables (FAO 1999 for Thailand). In Asia, some (but not all) vegetable seed companies and other input suppliers have invested heavily in farmer extension in the vegetable sector. Companies doing this can gain customer loyalty and increase seed sales. Government support of such extension efforts could accelerate the adoption of vegetable technologies. 


\subsection{Strengthen vegetable supply chains}

Farmers that grow for a defined market outlet are more likely to adopt improved varieties and new management practices. However, commercial vegetable production is risky for smallholders because the produce is perishable, so the marketing chain must be reasonably secure before farmers make these investments. Better market integration and more secure marketing chains will help to unlock the potential of vegetables to improve nutrition, create jobs and generate income in rural and peri-urban areas. Given the relatively sparse population in much of rural Africa and the continuing migration to cities, the main development in vegetable production will probably be close to cities, where it can provide much-needed employment. In contrast, most of Asia is more densely populated and has better roads so location close to markets is less important.

Key factors for improving vegetable marketing chains include better price information systems using communication technologies that are now readily available, forward contracting to hedge against fluctuating market prices, and improved postharvest handling facilities. Some of these positive changes are already happening in Africa as there has been rapid growth of small and medium-sized enterprises engaged in wholesaling, logistics, and processing (AGRA 2019).

Segmenting vegetable markets is a key aspect of this process. For example, in Tanzania, only one type of tomato is widely traded and the price is therefore largely determined by volume alone (Guijt and Reuver 2019). This makes the market, and ultimately producers, vulnerable to short-term oversupply and price instability. Segmenting markets according to fruit type and other quality aspects such as organic produce will help farmers to obtain better prices for their produce. It will also give consumers more choice and benefit other market chain actors, including seed companies. While this applies for all crops, it is especially relevant to vegetables because consumers are more alert to the quality attributes of fresh produce. The use of appropriate packaging will increase produce shelf life, reduce transport losses and create opportunities for local manufacturers. Farmer producer organizations, other aggregator models, and contract farming can also enhance farmer bargaining power in the value chain.

\section{Conclusion}

Considering the nutritional challenges facing the African continent, and the economic challenges of poverty and unemployment, it is essential to give higher priority to developing the vegetable sector. The rapid expansion of vegetable production and consumption in many Asian countries since the 1990s provides valuable lessons. One of the most important has been the critical role of the private sector in stimulating domestic breeding of well-adapted vegetable varieties so that farmers and consumers have better products and more choice. This will enable farmers to increase their production, thereby making vegetables more affordable to consumers, and likewise enable seed companies to assert their identity in the market place with distinct products. The experience of Asia over the past 30 years illustrates the need to create a favorable environment for private seed companies to develop their commercial potential through investment in R\&D. The key elements are to: (a) strengthen the capacity of African vegetable seed companies in research and seed production; (b) review and revise seed laws and regulations to give seed companies more incentive to invest in vegetable research and development; (c) provide extension programs to promote the adoption of improved production technologies; and (d) support vegetable supply chains to become more efficient, thus reducing the risk for farmers and traders. Investment by governments, international/regional organizations and donors in these key areas will put more "greens" into Africa's Green Revolution and help to energize the private seed sector, stimulate smallholder productivity and income growth, and help to address the many nutritional challenges now facing African countries.

Acknowledgments Authors 1 and 9-11 acknowledge funding support provided by long-term strategic donors to the World Vegetable Center, namely Taiwan, UK aid from the UK government, United States Agency for International Development (USAID), Australian Centre for International Agricultural Research (ACIAR), and the governments of Germany, Thailand, Philippines, Korea, and Japan. The paper benefitted from the constructive comments of this journal's editors and reviewers.

\section{Compliance with ethical standards}

Conflict of interest SNG is honorary chairman of East-West Seed, BP is staff of Advanta Seeds, LM and TC are staff of Seed Co., MN is staff of Simlaw Seeds. PS, VAS, PH and MW are staff of World Vegetable Center. $\mathrm{JH}$ is a member of the Board of Directors of World Vegetable Center.

Open Access This article is licensed under a Creative Commons Attribution 4.0 International License, which permits use, sharing, adaptation, distribution and reproduction in any medium or format, as long as you give appropriate credit to the original author(s) and the source, provide a link to the Creative Commons licence, and indicate if changes were made. The images or other third party material in this article are included in the article's Creative Commons licence, unless indicated otherwise in a credit line to the material. If material is not included in the article's Creative Commons licence and your intended use is not permitted by statutory regulation or exceeds the permitted use, you will need to obtain permission directly from the copyright holder. To view a copy of this licence, visit http://creativecommons.org/licenses/by/4.0/.

\section{References}

Abate, T., Fisher, M., Abdoulaye, T., Kassie, G. T., Lunduka, R., Marenya, P., \& Asnake, W. (2017). Characteristics of maize cultivars in Africa: How modern are they and how many do smallholder farmers grow? Agriculture \& Food Security, 6, 30. https://doi.org/ 10.1186/s40066-017-0108-6. 
Access to Seeds Index. (2019a). Access to seeds index 2019 eastern and southern Africa. Available online at: http://www.accesstoseeds.org/ index/eastern-southern-africa/. Accessed 15 November 2020.

Access to Seeds Index. (2019b). Access to seeds index 2019 Western and Central Africa. Available online at: http:/www.accesstoseeds.org/ index/western-central-africa/. Accessed 15 November 2020.

Advanta. (2019). India Vegetable Seed Sector: Volume in Kg for OP \& F1 Seeds (unpublished data). Advanta: Dubai, UAE.

Afari-Sefa, V., Tenkouano, A., Ojiewo, C. O., Keatinge, J. D. H., \& Hughes, J. d.' A. (2012). Vegetable breeding in Africa: Constraints, complexity and contributions toward achieving food and nutritional security. Food Security, 4(1), 115-127.

Afshin, A., Sur, P. J., Fay, K. A., Cornaby, L., Ferrara, G., Salama, J. S., Mullany, E. C., Abate, K. H., Abbafati, C., Abebe, Z., Afarideh, M., Aggarwal, A., Agrawal, S., Akinyemiju, T., Alahdab, F., Bacha, U., Bachman, V. F., Badali, H., Badawi, A., Bensenor, I. M., Bernabe, E., Biadgilign, S. K. K., Biryukov, S. H., Cahill, L. E., Carrero, J. J., Cercy, K. M., Dandona, L., Dandona, R., Dang, A. K., Degefa, M. G., el Sayed Zaki, M., Esteghamati, A., Esteghamati, S., Fanzo, J., Farinha, C. S. . S., Farvid, M. S., Farzadfar, F., Feigin, V. L., Fernandes, J. C., Flor, L. S., Foigt, N. A., Forouzanfar, M. H., Ganji, M., Geleijnse, J. M., Gillum, R. F., Goulart, A. C., Grosso, G., Guessous, I., Hamidi, S., Hankey, G. J., Harikrishnan, S., Hassen, H. Y., Hay, S. I., Hoang, C. L., Horino, M., Islami, F., Jackson, M. D., James, S. L., Johansson, L., Jonas, J. B., Kasaeian, A., Khader, Y. S., Khalil, I. A., Khang, Y. H., Kimokoti, R. W., Kokubo, Y., Kumar, G. A., Lallukka, T., Lopez, A. D., Lorkowski, S., Lotufo, P. A., Lozano, R., Malekzadeh, R., März, W., Meier, T., Melaku, Y. A., Mendoza, W., Mensink, G. B. M., Micha, R., Miller, T. R., Mirarefin, M., Mohan, V., Mokdad, A. H., Mozaffarian, D., Nagel, G., Naghavi, M., Nguyen, C. T., Nixon, M. R., Ong, K. L., Pereira, D. M., Poustchi, H., Qorbani, M., Rai, R. K., Razo-García, C., Rehm, C. D., Rivera, J. A., Rodríguez-Ramírez, S., Roshandel, G., Roth, G. A., Sanabria, J., Sánchez-Pimienta, T. G., Sartorius, B., Schmidhuber, J., Schutte, A. E., Sepanlou, S. G., Shin, M. J., Sorensen, R. J. D., Springmann, M., Szponar, L., Thorne-Lyman, A. L., Thrift, A. G., Touvier, M., Tran, B. X., Tyrovolas, S., Ukwaja, K. N., Ullah, I., Uthman, O. A., Vaezghasemi, M., Vasankari, T. J., Vollset, S. E., Vos, T., Vu, G. T., Vu, L. G., Weiderpass, E., Werdecker, A., Wijeratne, T., Willett, W. C., Wu, J. H., Xu, G., Yonemoto, N., Yu, C., \& Murray, C. J. L. (2019). Health effects of dietary risks in 195 countries, 1990-2017: A systematic analysis for the global burden of disease study 2017. The Lancet, 393, 1958-1972. https://doi.org/10. 1016/S0140-6736(19)30041-8.

AgConAsia Agriculture Consulting. (2017) Summary of Seed Related Laws in Thailand, China and India (2016). Available at: https:// agconasia.com/projects/seed-law-2/. Accessed 15 November 2020.

AGRA. (2018). Annual Report 2017: Catalyzing an inclusive transformation in Africa. Nairobi: Alliance for a Green Revolution in Africa.

AGRA. (2019). Africa Agriculture Status Report: The Hidden Middle: A Quiet Revolution in the Private Sector Driving Agricultural Transformation. Nairobi: Alliance for a Green Revolution in Africa.

Ali, M. (2000). Dynamics of vegetable production, distribution and consumption in Asia (p. 470). Shanhua: Asian Vegetable Research and Development Center.

Beal, T., Massiot, E., Arsenault, J. E., Smith, M. R., \& Hijmans, R. J. (2017). Global trends in dietary micronutrient supplies and estimated prevalence of inadequate intakes. PLoS One, 12, e0175554. https://doi.org/10.1371/journal.pone.0175554.

Beintema, N., \& Stads, G.-J. (2017). A Comprehensive Overview of Investments and Human Resource Capacity in African Agricultural Research. Washington, DC: International Food Policy Research Institute.

Birthal, P. S., Joshi, P. K., Roy, D., \& Thorat, A. (2013). Diversification in Indian agriculture toward high-value crops: The role of small farmers. Canadian Journal of Agricultural Economics/Revue Canadienne d'Agroeconomie, 61(1), 61-91.
Cernansky, R. (2015). The rise of Africa's super vegetables. Nature, 522(7555), 146-148.

Coomes, O. T., McGuire, S. J., Garine, E., Caillon, S., McKey, D., Demeulenaere, E., Jarvis, D., Aistara, G., Barnaud, A., Clouvel, P., Emperaire, L., Louafi, S., Martin, P., Massol, F., Pautasso, M., Violon, C., \& Wencélius, J. (2015). Farmer seed networks make a limited contribution to agriculture? Four common misconceptions. Food Policy, 56, 41-50.

Croft, M. M., Marshall, M. I., Odendo, M., Ndinya, C., Ondego, N. N., Obura, P., \& Hallett, S. G. (2018). Formal and informal seed Systems in Kenya: Supporting indigenous vegetable seed quality. The Journal of Development Studies, 54(4), 758-775.

Cromwell, E., Friis-Hansen, E., \& Turner, M. (1992). The seed sector in developing countries: A framework for performance analysis. $O D I$ Working Paper 65. Overseas Development Institute, London.

Das, B., Van Deventer, F., Wessels, A., Mudenda, G., Key, J., \& Ristanovic, D. (2019). Role and challenges of the private seed sector in developing and disseminating climate-smart crop varieties in eastern and southern Africa. In T. Rosenstock, A. Nowak, \& E. Girvetz (Eds.), The Climate-Smart Agriculture Papers. Cham: Springer.

Dawe, D. (2000). The contribution of rice research to poverty alleviation. In J. E. Sheehy, P. L. Mitchell, \& B. Hardy (Eds.), Redesigning rice photosynthesis to increase yield. Proceedings of the Workshop on The Quest to Reduce Hunger: Redesigning Rice Photosynthesis, 30 Nov.-3 Dec. 1999, Los Baños. Philippines (pp. 3-12). Manila: International Rice Research Institute.

Erenstein, O., \& Kassie, G. (2018). Seeding eastern Africa's maize revolution in the post-structural adjustment era: A review and comparative analysis of the formal maize seed sector. International Food and Agribusiness Management Review, 21(1), 39-52.

Evenson, R. E., \& Gollin, D. (2003). Assessing the impact of the green revolution, 1960 to 2000. Science, 300, 758-762.

FAO. (1999). The vegetable sector in Thailand. RAP Publication 1999/38. Food and agriculture Organization of the United Nations, Regional Office for Asia and the Pacific, Bangkok.

FAO. (2020). Status of seed legislation and policies in the Asia-Pacific region. Regional Office for Asia and the Pacific, Food and Agriculture Organization of the United Nations, Bangkok. https:// doi.org/10.4060/CA7599EN.

FAO, ECA \& AUC. (2020). Africa regional overview of food security and nutrition 2019: Containing the damage of economic slowdowns and downturns to food security in Africa. Accra: Food and Agriculture Organization of the United Nations, Economic Commission for Africa, African Union Commission. https://doi. org/10.4060/CA7343EN.

FAOSTAT. (2019). FAOSTAT Database on Production. FAO statistics division, food and agriculture Organization of the United Nations, Rome. Available online at http://www.fao.org/faostat/en/\#data. Accessed 14 Aug. 2019.

Global Panel. (2016). Food systems and diets: Facing the challenges of the 21st century. London: Global Panel on Agriculture and Food Systems for Nutrition.

Glover, D., Kumar, A., Alemu, D., Odame, H., Akwara, M., \& Scoones, I. (2015). Indian seeds in Africa: A scoping study of challenges and opportunities. Brighton: FAC Working Paper 135. Institute of Development Studies.

Gray, G., \& Kohl, R. (2016). Scaling up of drought-tolerant maize in Zambia: Review of successful scaling of agricultural technologies. Washington, DC: Management Systems International.

Guijt, J., \& Reuver, R. (2019). Seed companies and the Tanzanian horticulture sector. Wageningen: Centre for Development Innovation. https://doi.org/10.18174/475373.

Herforth, A., Masters, W., Bai, Y., \& Sarpong, D. (2019). The cost of recommended diets: Development and application a food Price index based on food-based dietary guidelines (P10-033-19). Current 
Developments in Nutrition. https://doi.org/10.1093/cdn/nzz034. P10-033-19.

Hirvonen, K., Bai, Y., Headey, D., \& Masters, W. A. (2020). Affordability of the EAT-lancet reference diet: A global analysis. The Lancet Global Health, 8, e59-e66. https://doi.org/10.1016/S2214-109X(19)30447-4.

IHS Markit Agribusiness Consulting. (2019). Analysis of sales and profitability within the seed sector. Independent report prepared for the co-chairs of the ad-hoc open-ended working group to enhance the functioning of the Multilateral System of Access and Benefit-sharing of FAO'S International Treaty on Plant Genetic Resources for Food and Agriculture. IHS Markit Agribusiness Consulting. Available at: http:// www.fao.org/3/ca6929en/ca6929en.pdf. Accessed November 2020.

Joughin, J. (2014). The political economy of seed reform in Uganda: Promoting a regional seed trade market. Washington, DC: Africa Trade Practice Working Paper Series Number 3. World Bank.

Kalmpourtzidou, A., Eilander, A., \& Talsma, E.F. (2020). Global vegetable intake and supply compared to Recommendations: A Systematic Review. Nutrients. https://doi.org/10.3390/nu12061558.

Kolady, D. E., Spielman, D. J., \& Cavalieri, A. (2012). The impact of seed policy reforms and intellectual property rights on crop productivity in India. Journal of Agricultural Economics, 63(2), 361-384.

Koundinya, A. V. V., \& Kumar, P. P. (2014). Indian vegetable seeds industry: Status and challenges. The International Journal of Plant, Animal and Environmental Sciences, 4(4), 62-69.

Kuhlmann, K. \& Zhou, Y. (2015). Seed Policy Harmonization in ECOWAS: The Case of Ghana. Syngenta Foundation for Sustainable Agriculture, Basel, Switzerland. Available at: https:// www.syngentafoundation.org/sites/g/files/zhg576/f/seeds_policy_ ghana_seed_case_study_jan16_0_1.pdf. Accessed November 2020.

Louwaars, N. P., \& de Boef, W. S. (2012). Integrated seed sector development in Africa: A conceptual framework for creating coherence between practices, programs, and policies. Journal of Crop Improvement, 26(1), 39-59.

Ma, S., Huang, J., Wang, D., \& Qu, D. (2000). China. In M. Ali (Ed.), Dynamics of vegetable production, distribution and consumption in Asia (pp. 69-98). Shanhua: Asian Vegetable Research and Development Center.

Mason-D'Croz, D., Bogard, J. R., Sulser, T. B., Cenacchi, N., Dunston, S., Herrero, M., \& Wiebe, K. (2019). Gaps between fruit and vegetable production, demand, and recommended consumption at global and national levels: An integrated modelling study. The Lancet Planetary Health, 3, e318-e329. https://doi.org/10.1016/S2542-5196(19)30095-6.

Masters, W. A., Bai, Y., Herforth, A., Sarpong, D. B., Mishili, F., Kinabo, J., \& Coates, J. C. (2018). Measuring the affordability of nutritious diets in Africa: Price indexes for diet diversity and the cost of nutrient adequacy. American Journal of Agricultural Economics, 100(5), $1285-1301$.

Matuschke, I., Mishra, R. R., \& Qaim, M. (2007). Adoption and impact of hybrid wheat in India. World Development, 35(8), 1422-1435.

Mehta, S., Lal, R., \& Hansen, D. (2017). US land-grant universities in India: Assessing the consequences of agricultural partnership, 1952-1972. International Journal of Educational Development, 53, 58-70.

Nelson, G., Bogard, J., Lividini, K., Arsenault, J., Riley, M., Sulser, T. B., Mason-D’Croz, D., Power, B., Gustafson, D., Herrero, M., Wiebe, K., Cooper, K., Remans, R., \& Rosegrant, M. (2018). Income growth and climate change effects on global nutrition security to mid-century. Nature Sustainability, 1(12), 773-781.

Pingali, P. L. (2012). Green revolution: Impacts, limits, and the path ahead. Proceedings of the National Academy of Sciences, 109(31), 12302.

Pingali, P. (2015). Agricultural policy and nutrition outcomes - Getting beyond the preoccupation with staple grains. Food Security, 7(3), 583-591.

Pray, C. E., \& Nagarajan, L. (2014). The transformation of the Indian agricultural input industry: Has it increased agricultural R\&D? Agricultural Economics, 45(S1), 145-156.
Pray, C. E., Ramaswami, B., \& Kelley, T. (2001). The impact of economic reforms on R\&D by the Indian seed industry. Food Policy, 26(6), 587-598.

Schreinemachers, P., Sequeros, T., \& Lukumay, P. J. (2017a). International research on vegetable improvement in east and southern Africa: Adoption, impact, and returns. Agricultural Economics, 48, 707-717. https://doi.org/10.1111/agec. 12368.

Schreinemachers, P., Rao, K. P. C., Easdown, W., Hanson, P., \& Kumar, S. (2017b). The contribution of international vegetable breeding to private seed companies in India. Genetic Resources and Crop Evolution, 64(5), 1037-1049. https://doi.org/10.1007/s10722-0160423-y.

Schreinemachers, P., Simmons, E. B., \& Wopereis, M. C. S. (2018). Tapping the economic and nutritional power of vegetables. Global Food Security, 16, 36-45. https://doi.org/10.1016/j.gfs.2017.09.005.

Smale, M., Byerlee, D., \& Jayne, T. (2011). Maize revolutions in subSaharan Africa. World Bank policy research working paper no. 5659. The World Bank: Washington, D.C.

Sperling, L., Gallagher, P., McGuire, S., \& March, J. (2020). Tailoring legume seed markets for smallholder farmers in Africa. International Journal of Agricultural Sustainability, 1-20. https:// doi.org/10.1080/14735903.2020.1822640.

Spielman, D. J., Kolady, D. E., \& Ward, P. S. (2013). The prospects for hybrid rice in India. Food Security, 5(5), 651-665.

Staatz, J., \& Hollinger, F. (2016). West African Food Systems and Changing Consumer Demands. Paris: West African Papers, No. 4, OECD Publishing. https://doi.org/10.1787/b165522b-en.

The Economic Times. (2018). Domestic vegetable seeds industry to hit Rs 8,000 crore in 5 years: Report. 22 March 2018.

Timmer, C.P. (2009). Rice Price formation in the short run and long run: The role of market structure in explaining volatility. Working Paper 172. Center for Global Development: Washington, DC.

Traimongkolkul, P., \& Tanpichai, P. (2005). Lessons learned and present prospects: A critical review of agricultural education in Thailand. Journal of International Agricultural Education, 12, 53-65.

Tripp, R., \& Rohrbach, D. (2001). Policies for African seed enterprise development. Food Policy, 26(2), 147-161.

Tschirley, D., Reardon, T., Dolislager, M., \& Snyder, J. (2015). The rise of a middle class in east and southern Africa: Implications for food system transformation. Journal of International Development, 27(5), 628-646.

Turner, M.R. \& Bishaw, Z. (2016). A review of variety release procedures and related issues with recommendations for good practice. ICARDA Working Paper 31. International Center for Agricultural Research in the Dry Areas, Beirut, Lebanon.

UN. (2015). Youth population trends and sustainable development. Population Facts May 2015 No. 2015/1 United Nations, Department of Economic and Social Affairs, Population Division. Available at: https://www.un.org/esa/socdev/documents/youth/factsheets/YouthPOP.pdf. Accessed 27 June 2020.

United Nations Population Division. (2019). World Urbanization Prospects: The 2018 Revision (ST/ESA/SER.A/420). United Nations, Department of Economic and Social Affairs, Population Division, New York.

Walker, T. S., \& Alwang, J. (2015). Crop improvement, adoption and impact of improved varieties in food crops in sub-Saharan Africa. Wallingford: CABI Publishing.

Walker, T. S., Alwang, J., Alene, A., Ndjuenga, J., Labarta, R., Yigezu, Y., Diagne, A., Andrade, R., Andriatsitohaina, R. M., Groote, H. D., Mausch, K., Yirga, C., Simtowe, F., Katungi, E., Jogo, W., Jaleta, M., Pandey, S., \& Charyulu, D. K. (2015). Varietal adoption, outcomes and impact. In T. S. Walker \& J. Alwang (Eds.), Evaluating the performance of food crop improvement research in sub-Saharan Africa from the perspectives of varietal output, adoption, and change. Wallingford: CABI Publishing. 
WHO. (2015). The global prevalence of anaemia in 2011. Geneva: World Health Organization.

WHO. (2019). Atlas of African Health Statistics 2019. African health observatory, World Health Organization Regional Office for Africa Brazzaville, Congo.

Willett, W., Rockstrom, J., Loken, B., et al. (2019). Food in the Anthropocene: The EAT-lancet commission on healthy diets from sustainable food systems. The Lancet, 393, 447-492. https://doi.org/ 10.1016/S0140-6736(18)31788-4.

Wise, T. A. (2020). Failing Africa's Farmers: An Impact Assessment of the Alliance for a Green Revolution in Africa. Global Development and Environment Institute Working Paper 20-01. Boston, MA: Tufts University.

Worku, I. H., Dereje, M., Minten, B., \& Hirvonen, K. (2017). Diet transformation in Africa: The case of Ethiopia. Agricultural Economics, 48(S1), 73-86.

Zhou, Y., \& Staatz, J. (2016). Projected demand and supply for various foods in West Africa: Implications for investments and food policy. Food Policy, 61(C), 198-212.

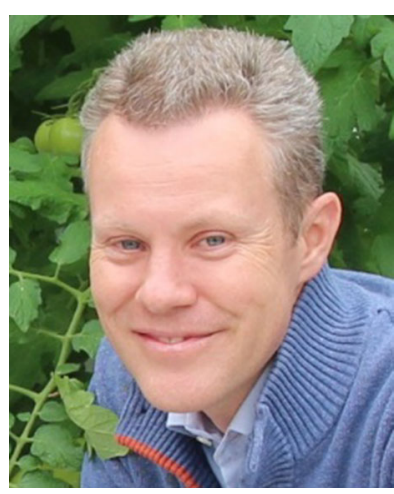

Pepijn Schreinemachers is an Agricultural Economist with the World Vegetable Center where he leads the flagship research programs on "Enabling Impact" and "Healthy Diets". Previously, he was project coordinator of "The Uplands Program" at Hohenheim University. Pepijn holds a PhD from the Center for Development Research (ZEF), University of Bonn, Germany and an MSc in Development Studies from Wageningen University, the Netherlands.

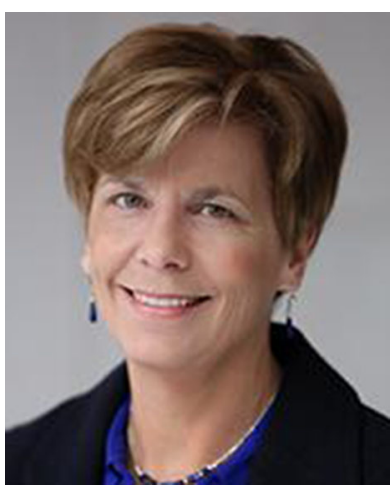

Julie Howard is an independent consultant on international agricultural development. She is Senior Adviser (non-resident) at the Center for Strategic and International Studies and a member of the Board of Directors of the World Vegetable Center. Previously she served as senior adviser to the USAID administrator on agricultural research, extension, and education.

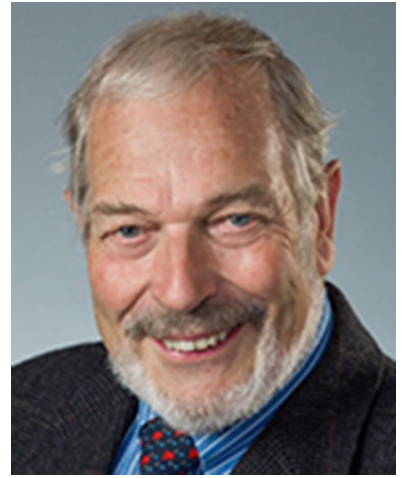

Michael Turner is an independent consultant on seed issues for many different development organizations and companies. Much of his recent work has focused on seed legislation and policies, which are a concern in many countries undergoing economic liberalization and transition of the agricultural sector. He has worked in different aspects of seeds for 45 years. He was Director of the Postgraduate Course in Seed Technology at the University of Edinburgh, UK for 18 years and also served as head of the Seed Unit at the International Center for Agricultural Research in the Dry Areas (ICARDA).

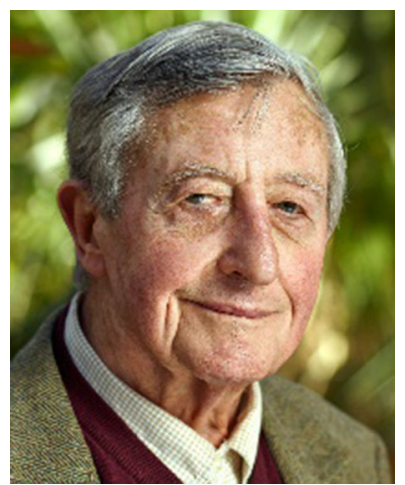

Simon N. Groot is founder and honorary chairmen of EastWest Seed. He was awarded the World Food Prize in 2019 in recognition of East-West Seed's contribution to improving nutrition and creating sustainable economic opportunities for small farmers around the world. Simon Groot started East-West Seed in the Philippines in 1982 and then extended the company's business into South and Southeast Asia and Africa. $\mathrm{He}$ is also one of the founding fathers of the Asia and Pacific Seed Association (APSA).

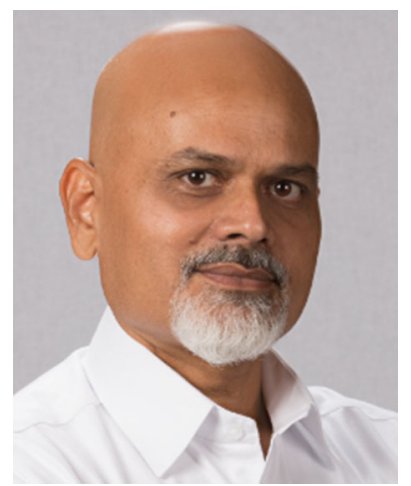

Bhupen Dubey is Chief Executive Officer of Advanta Seeds, part of the UPL group. $\mathrm{He}$ is a well-known Thought Leader in the seed industry with several affiliations in social and scientific bodies namely Chairman of Special Interest Group at APSA, National Seed Association of India, India Business Council (World Economic Forum) etc. With his depth of business experience and strategic leadership, he has been instrumental in setting the strategic direction for Advanta and expand Advanta's footprint across the globe. He has over 30 years of experience in the food production industry with several global enterprises such as Hoechst, Agrevo, Aventis (part of Bayer Crop Science) and also in crop protection at various leadership positions in UPL. 


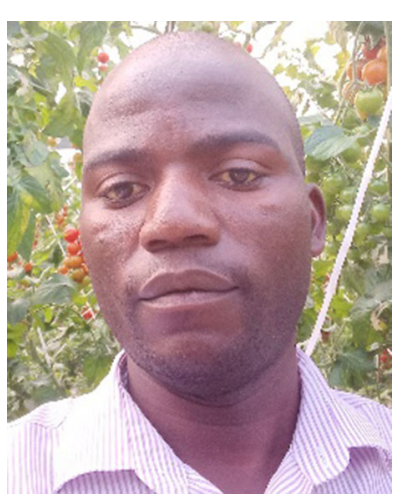

Learnmore Mwadzingeni is Product Development Manager for Seed Co Vegetables, and oversees vegetable research and development for the organization. He has expertise in plant breeding, with experience in vegetable and field crops. Prior to joining Seed $\mathrm{Co}$, he worked for the African Center for Crop Improvement (ACCI) and was affiliated to the Agriculture Research CouncilSmall Grains Institute (ARCSGI) in South Africa.

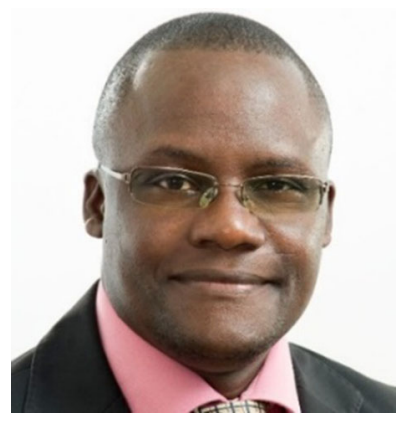

Takemore Chagomoka is Business Development Manager at Seed Co West and Central Africa. He has extensive experience in the agrochemical industry, horticultural industry and seed industry. His research interests are on urban and peri-urban agriculture in developing countries, Geographic Information Systems (GIS), socio-spatial dynamics of food and nutrition security in sub-Sahara Africa.

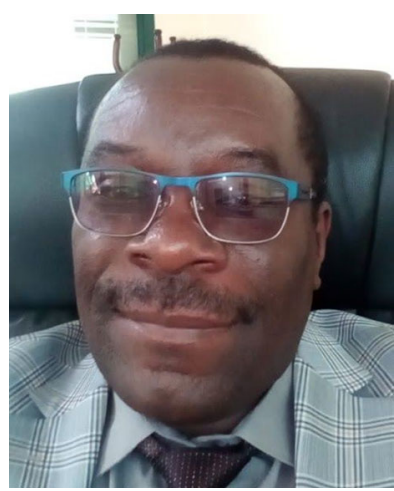

Michael Ngugi is the head of Technical Services at Simlaw Seeds company based in Kenya but with branches in Tanzania and Uganda. He has extensive experience in the development of vegetable varieties and with a special interest in African indigenous vegetables. He has worked in the areas of breeding, seed production, processing and quality assurance for over 30 years. He also trains young scientists involved in research and production of veg-

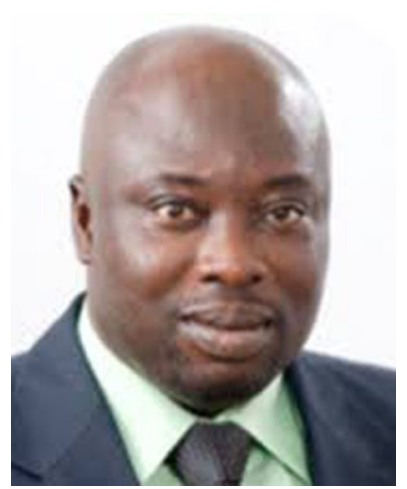

Victor Afari-Sefa is the Regional Director for West and Central Africa - Coastal and Humid Regions at World Vegetable Center. He has extensive experience in performance monitoring and impact assessment of horticultural value chains on smallholder livelihoods. His research focuses on assessing opportunities and challenges in vegetable production systems, analysing constraints in the value chain, and policy in interdisciplinary context.

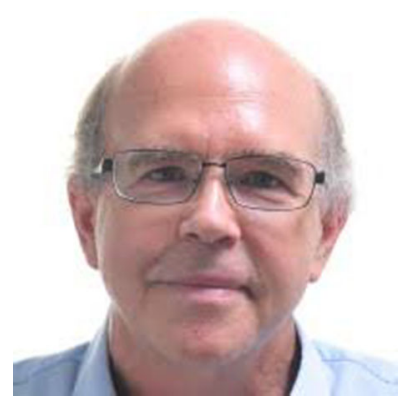

Peter Hanson is Lead Scientist Global Plant Breeding at the World Vegetable Center. He has extensive international experience in vegetable breeding, with a particular focus on tomato and crucifers. He works on the development of fresh market and processing tomato inbred lines and hybrids for the tropics, with emphasis on heat tolerance and multiple disease resistance, particularly begomoviruses, bacterial wilt, and late blight. Prior to joining the Center in 1993 he worked at Centro Internacional de Agricultura Tropicál (CIAT) in Colombia and at Egerton University in Kenya. etable seeds.

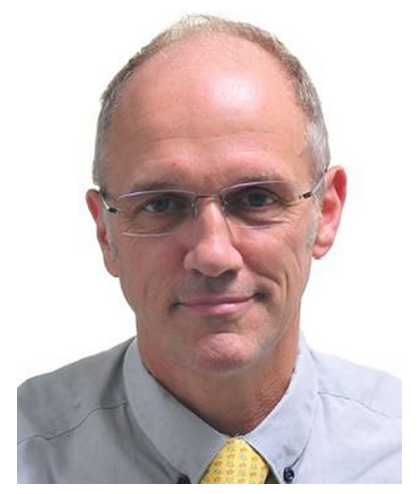

Marco C.S. Wopereis is the Director General of the World Vegetable Center and based in Taiwan. Prior to his current position he served as the Deputy Director General of the Africa Rice Center (AfricaRice, Benin). $\mathrm{He}$ also worked for the French Agricultural Research Centre for International Development (CIRAD, France), the International Fertilizer Development Center (IFDC, Togo), the West Africa Rice Development Association (WARDA, Senegal, Côte d'Ivoire) and the International Rice Research Institute (IRRI, Philippines). 